\title{
Collection, Utilization, and Preservation of Fruit Crop Genetic Resources-Some Case Studies: Introduction to the Workshop
}

\author{
Stan C. Hokanson ${ }^{1}$ \\ U.S. Department of Agriculture-Agricultural Research Service Fruit Laboratory, 10300 Baltimore Avenue, \\ Beltsville, MD 20705-2350
}

Much has been said and written regarding the potential of crop genetic resources to improve the quality and quantity of the world's food supply. The need to increase and improve our food supply is inescapable given current and projected human population statistics. The world population was estimated to have surpassed 6 billion sometime in 1999 and, if growth continues at the current rate, the population is expected to reach over 10 billion by the year 2100 (Brown and Flavin, 1999).

Clearly, our success at producing food has played a role in the tremendous growth in population. Whereas at the beginning of the century each farmer in the United States fed seven other Americans, today each farmer feeds 96 other people (Brown, 1999)! This agricultural success has come at a price. As the population has grown, so has the increase in the need for quick gains in quality and productivity of

Received for publication 22 May 2000. Accepted for publication 13 June 2000. The cost of publishing this paper was defrayed in part by the payment of page charges. Under postal regulations, this paper therefore must be hereby marked advertisement solely to indicate this fact.

${ }^{1}$ E-mail address: hokansos@ba.ars.usda.gov our crops. The tremendous increase in crop yields and quality have resulted in part from an overreliance on an increasingly narrowed domesticated gene pool.

Higher-yielding fruit crops will not directly address world hunger issues. However, an accumulating body of research suggests that an increased intake of fruits and vegetables, replete with antioxidants, vitamins, minerals, and undiscovered nutriceuticals, can contribute to a reduced risk of cardiovascular disease and certain forms of cancer (Blevins and Morris, 1997; Bradley and Shinton, 1998; Clinton, 1998; Kalt and Dufour, 1997; Wang et al., 1996), in addition to providing the well-known benefits of the essential vitamins and minerals.

The production of high-quality fruit crops also serves to diversify the agricultural economy, providing opportunities for growers to produce high-value crops. According to the National Agricultural Statistics Service (NASS; 2000), strawberries (Fragaria $\times$ ananassa Duchesne) were harvested from 18,452 ha in the United States in 1999. The yield was estimated to be $44,576 \mathrm{~kg} \cdot \mathrm{ha}^{-1}$, resulting in a production for the year of nearly $823,000 \mathrm{t}$ of fruit. Based on a value of $\$ 1.37 / \mathrm{kg}$, the total value of the crop for 1999 was estimated to be $>\$ 1.1$ billion U.S. The value of the crop to U.S. growers averaged $\approx \$ 61,000 / \mathrm{ha}$. By 
comparison, based on 1998 NASS data, returns for the U.S. corn (Zea mays L.), wheat [Triticum aestivum (L.) Thell.], and soybean [Glycine $\max$ (L.) Merr.] crops were $\$ 642, \$ 282$, and $\$ 474$ per hectare, respectively (National Agricultural Statistics Service, 2000). Thus, although for different reasons, the critical issues of collecting, preserving, understanding, and utilizing the genetic resources associated with fruit crops are no different from those for our more high-profile commodity crops.

Genetic resources have contributed important traits to several such crops, including resistance to late blight [caused by Phytophthora infestans (Mont.) de Bary] in potato (Solanum tuberosum L.) (Nelson, 1978; Niederhauser and Cobb, 1959), stem rust (caused by Puccinia graminis Pers.: Pers. f. sp. tritici) in wheat (Roelfs, 1988), and grassy stunt virus in rice (Oryza sativa L.) (Cabauatan et al., 1985; Chang, 1989). Genes from wild relatives have had dramatic impacts on fruit industries as well. The day-neutrality trait discovered in several sources, most notably a Fragaria virginiana Duch. ssp. glauca clone (Bringhurst and Voth, 1984), has revolutionized the California strawberry industry. This trait is worth an estimated $\$ 80$ million per year to the California industry alone (Douglas Shaw, pers. comm.). Paradoxically, resistance to phylloxera [Daktulosphaira vitifoliae (Fitch)], achieved primarily by grafting susceptible cultivars of grape (Vitis sp.) on North American species, but also through interspecific hybridization to several North American Vitis species (Bouquet, 1983; Firoozabady and Olmo, 1982), saved the European grape industry from this North American pest. Based on Food and Agricultural Organization (FAO) (2000) data, Europe and the Baltic states produced $>19$ million $t$ of wine grapes in 1998. Assuming that $90 \%$ of these vines were grafted on rootstocks derived from North American Vitis species and that the wine exports were worth $\$ 11.6$ billion to the industry, the value of the North American germplasm could be construed to exceed $\$ 10$ billion in that single year!

Germplasm collections have been developed for all our major agricultural crops, including fruit crops (Brooks and Barton, 1977). Some criticisms have been voiced regarding the composition of such collections, and the manner in which they are characterized and maintained (Fowler and Mooney, 1990; Nabhan, 1989; Plucknett et al., 1987; Tuxill, 1999). We presently maintain large collections of cultivated germplasm for most of our fruit crops, and some collections of crops, such as apple, have a good range of species accessions. In contrast, other crops, such as Vaccinium (see Ballington, 2001) and Rubus, are underrepresented with regard to species, and collection activities should continue to be a priority. For many of our fruit crops, excellent efforts are under way to characterize the collections and make them more useful to breeders. However, despite the outstanding examples of the real value of the germplasm resources and the academic understanding of the need to utilize germplasm resources, one of the primary criticisms of the whole system is the general reluctance to use such divergent germplasm in traditional breeding programs. This reluctance stems from the suite of negative traits that are typically transmitted with the desired trait when making hybrids with wild species, and the time and effort involved in the backcrossing necessary to eliminate such traits. Despite this general reluctance, some programs are actively utilizing germplasm resources as major elements in their breeding programs, and several of these programs are described in this workshop.

Along with consuming more food, our increasing population is also impacting habitat critical to some of our crop genetic resources. Until quite recently, all of the fruit germplasm collections were maintained as seed or clonal accessions at various ex situ locations. A primary weakness of an ex situ germplasm preservation system is that the collections become genetically static, no longer being subjected to pests and pathogens, abiotic stresses, and other selective agents that result in continued evolution of new traits and characters (Maxted et al., 1997; Zencirci et al., 1998). In these proceedings, a pioneering pilot project designed to investigate the potential for developing in situ preservation strategies for native American Vitis germplasm resources is described.

Hopefully, the projects detailed herein mark the beginnings of a new phase for plant genetic resources conservation. This era would highlight a much more active phase of genetic resources utilization, wherein the long-stated promises of genetic resources would come closer to realization. In addition, it would be an era where the conservation of crop genetic resources would become more integrated and multidimensional, simultaneously allowing for secure preservation and continued evolution of new traits and characters (Bretting and Duvick, 1997).

\section{Literature Cited}

Ballington, J.R. 2001. Collection, utilization, and preservation of genetic resources in Vaccinium. HortScience 36:213-220.

Blevins, J.M. and J.R. Morris. 1997. Health benefits of wine and grape juice. HortScience 7:228-233.

Bouquet, A. 1983. Etude de la résistance au phylloxera radicicole des hybrides Vitis vinifera $\times$ Muscadinia rotundifolia. Vitis 22:311-323.

Bradley, S. and R. Shinton. 1998. Why is there an association between eating fruit and vegetables and a lower risk of stroke? J. Hum. Nutr. Dietet. 11:363-372.

Bretting, P.K. and D.N. Duvick. 1997. Dynamic conservation of plant genetic resources. Adv. Agron. 61:1-51.

Bringhurst, R.S. and V. Voth. 1984. Breeding octoploid strawberries. Iowa State J. Res. 58:371-381.

Brooks, H.J. and D.W. Barton. 1977. A plan for national fruit and nut germplasm repositories. HortScience 12:298-300.

Brown, L.R. 1999. Feeding nine billion, p. 115-132. In: L. Starke (ed.). State of the world 1999. W.W. Norton, New York.

Brown, L.R. and C. Flavin. 1999. A new economy for a new century, p. 3-21. In: L. Starke (ed.). State of the world 1999. W.W. Norton, New York.

Cabauatan, P.Q., H. Hibino, D.B. Lapis, T. Omura, and T. Tsuchizaki. 1985 Rice grassy stunt virus 2: A new strain of rice grassy stunt in the Philippines. IRRI Res. Paper Ser. No. 106. Intl. Rice Res. Inst., Los Banos, Philippines.

Chang, T.T. 1989. The case for large collections, p. 123-135. In: A.H.D. Brown, O.H. Frankel, D.R. Marshall, and J.T. Williams (eds.). The use of plant genetic resources. Cambridge Univ. Press, Cambridge, U.K.

Clinton, S.K. 1998. Lycopene: Chemistry, biology, and implications for human health and disease. Nutr. Rev. 56:35-51.

Firoozabady, E. and H.P. Olmo. 1982. Resistance to grape phylloxera in Vitis vinifera $\times$ V. rotundifolia grape hybrids. Vitis $21: 1-4$.

Food and Agriculture Organization. 2000. FAOSTAT database collections. Rome, Italy. http://apps.fao.org/cgi-bin/nph-db.pl?subset=agriculture

Fowler, C. and P. Mooney. 1990. Shattering: Food, politics, and the loss of genetic diversity. Univ. of Arizona Press, Tucson.

Kalt, W. and D. Dufour. 1997. Health functionality of blueberries. HortTechnology 7:216-221.

Maxted, N., B.V. Ford-Lloyd, and J.G. Hawkes (eds.). 1997. Plant genetic conservation: The in-situ approach. Chapman and Hall, New York.

Nabhan, G.P. 1989. Enduring seeds: Native American agriculture and wild plant conservation. North Point Press, San Francisco.

National Agricultural Statistics Service. 2000. Reports by commodity index of estimates. http://www.usda.gov/nass/pubs/estindx.htm

Nelson, R.R. 1978. Genetics of horizontal resistance to plant diseases. Annu. Rev. Phytopathol. 15:359-378.

Niederhauser, J.S. and W.C. Cobb. 1959. The late blight of potatoes. Sci. Amer. 200:100-112.

Plucknett, D.L., N.J.H. Smith, J.T. Williams, and N.M. Anishetty. 1987. Gene banks and the world's food. Princeton Univ. Press, Princeton, N.J.

Roelfs, A.P. 1988. Resistance to leaf and stem rusts in wheat, p. 10-22. In: N.W. Simmonds and S. Rajaram (eds.). Breeding strategies for resistance to the rusts of wheat. CIMMYT (International Maize and Wheat Improvement Center), Mexico.

Tuxill, J. 1999. Appreciating the benefits of plant biodiversity, p. 96-114. In: L. Starke (ed.). State of the world 1999. W.W. Norton, New York.

Wang, H., G. Cao, and R.L. Prior. 1996. Total antioxidant capacity of fruits. J. Agr. Food Chem. 44:701-705.

Zencirci, N., Z. Kaya, Y. Anikster, and W.T. Adams (eds.). 1998. The proceedings of the international symposium on in situ conservation of plant genetic diversity. Central Res. Inst. for Field Crops. Ankara, Turkey. 